\title{
Secondary succession of woody plants following sand mining in the Soesdyke-Linden area, Guyana: A Chronosequence study
}

\author{
Sherilyn Jeanette Inniss * \\ Faculty of Earth and Environmental Sciences, University of Guyana, Turkeyen Campus, Guyana.
}

GSC Biological and Pharmaceutical Sciences, 2021, 17(01), 067-081

Publication history: Received on 30 August 2021; revised on 04 October 2021; accepted on 06 October 2021

Article DOI: https://doi.org/10.30574/gscbps.2021.17.1.0300

\begin{abstract}
Sandy soils comprise a large proportion of low productivity areas of Guyana on the Soesdyke-Linden Highway, where there is ecological disturbance and evidence of secondary succession after sand mining activities. This study investigated secondary succession of woody plants on abandoned sand mining locations. Secondary succession was studied inferentially by comparing sites in a homogeneous zone that was abandoned at different times post disturbance due to sand mining. Species diversity and community composition at five (5) sites which included an undisturbed area and areas at $3,5,10$, and 15 years after the disturbance of sand mining were studied. Fifteen $10 \mathrm{~m} \times 10 \mathrm{~m}$ plots were sampled for woody plants with a DBH of more than $2.5 \mathrm{~cm}$, and $1 \mathrm{~m} \times 1 \mathrm{~m}$ sub-plots were randomly selected and sampled for seedlings with a DBH less than $2.5 \mathrm{~cm}$. A total of 241 plants were recorded, encompassing 22 species across 16 Families. Tapiria marchandii of the family Anacardiaceae dominated the chronosequences of 5, 10, and 15 years and recorded the highest Importance Value Index (IVI) of 112.88, 154.51, and 215.42, respectively. Dimorphandra conjugata of the family Fabaceae also adapted well to conditions post sand mining in the latter chronosequences of 10 and 15 years with IVIs of 54.17 and 38.83, respectively. The youngest site of three years exhibited the highest species diversity post the disturbance of sand mining; however, the undisturbed site possessed the highest overall species diversity. Species diversity of chronosequences decreased with age as competition for limited resources increased and the dominant species proliferated.
\end{abstract}

Keywords: Sand Mining; Disturbance; Secondary Succession; Chronosequence; Woody Plants

\section{Introduction}

\subsection{Study Background}

The United Nations Environment Programme (UNEP) reports that sand is the third most used resource on the planet [1]. Fifty billion tonnes of sand and gravel are used worldwide annually, which accounts for $85 \%$ of the weight of minerals mined globally [2]. Economic development in numerous parts of the world has led to an escalation in demand for sand and gravel as materials for construction [3]. Likewise, the rise in urbanisation and construction of large-scale infrastructure projects are driving this demand globally [4]. Filho [5] alluded that the magnitude of the demand can be assessed if one considers the fact that one tonne of cement can require up to 10 tonnes of sand to make concrete [5]. John [6] and UNEP [1] both emphasized that extraction rates are exceeding natural sand replenishment rates coupled with an inadequate assessment of the wider environmental consequences of over-exploitation [6, 1]. Thus, the magnitude of this challenge makes it one of the major sustainability challenges of the 21st century [7].

Guyana's population is approximately 782,766 persons [8], where $90 \%$ of the population lives on the coast, which accounts for only $10 \%$ of the total land area. The population, along with administrative and commercial activities, are

\footnotetext{
* Corresponding author: Sherilyn Jeanette Inniss

Faculty of Earth and Environmental Sciences, University of Guyana, Turkeyen Campus, Guyana. 
concentrated in Region 4, particularly in Georgetown, the capital city. There has been strong economic growth in Guyana since 2010 [9], with growth rates consistently amongst the highest in South America. Guyana's economy has been described as the fastest-growing economy globally, and the Ministry of Finance, Guyana, has reported that Guyana's economy is projected to experience a high real growth rate in the immediate term, reflecting increased oil production [10].

With the advent of oil discoveries, Guyana has seen significant flows of foreign direct investment and, thus, people into Guyana. This has had a marked impact in several areas and sectors but is especially visible in the additional stress it has added to Guyana's construction sector and existing road and riverain infrastructure. With the continued urbanisation and the expansion of the housing [11] and infrastructure sectors to support the growing population and economic development, there has been an increase in the demand for sand for construction purposes. Consequently, there has been significant land degradation caused by the extraction of sand on the Soesdyke-Linden Highway, with some of these sand mining areas being abandoned without any land reclamation or rehabilitation activities undertaken (Figure1).

Moreover, after years of sand mining along the Soesdyke-Linden Highway there appears to be a loss of the primary vegetation cover, the extent to which may have resulted in a change in the plant community structure. Therefore, this study sought to investigate secondary succession of woody plants on abandoned sand mining locations along the Soesdyke-Linden Highway. Specific objectives included identifying abandoned sand mining areas of varying successional years and assessing the floristic composition and diversity of woody plants through the conduct of a forest inventory. Accordingly, information on ecological successional trends within the study area will be useful to assist the development of sustainable sand mining management strategies and for planning future management approaches in the extractive sector of Guyana.

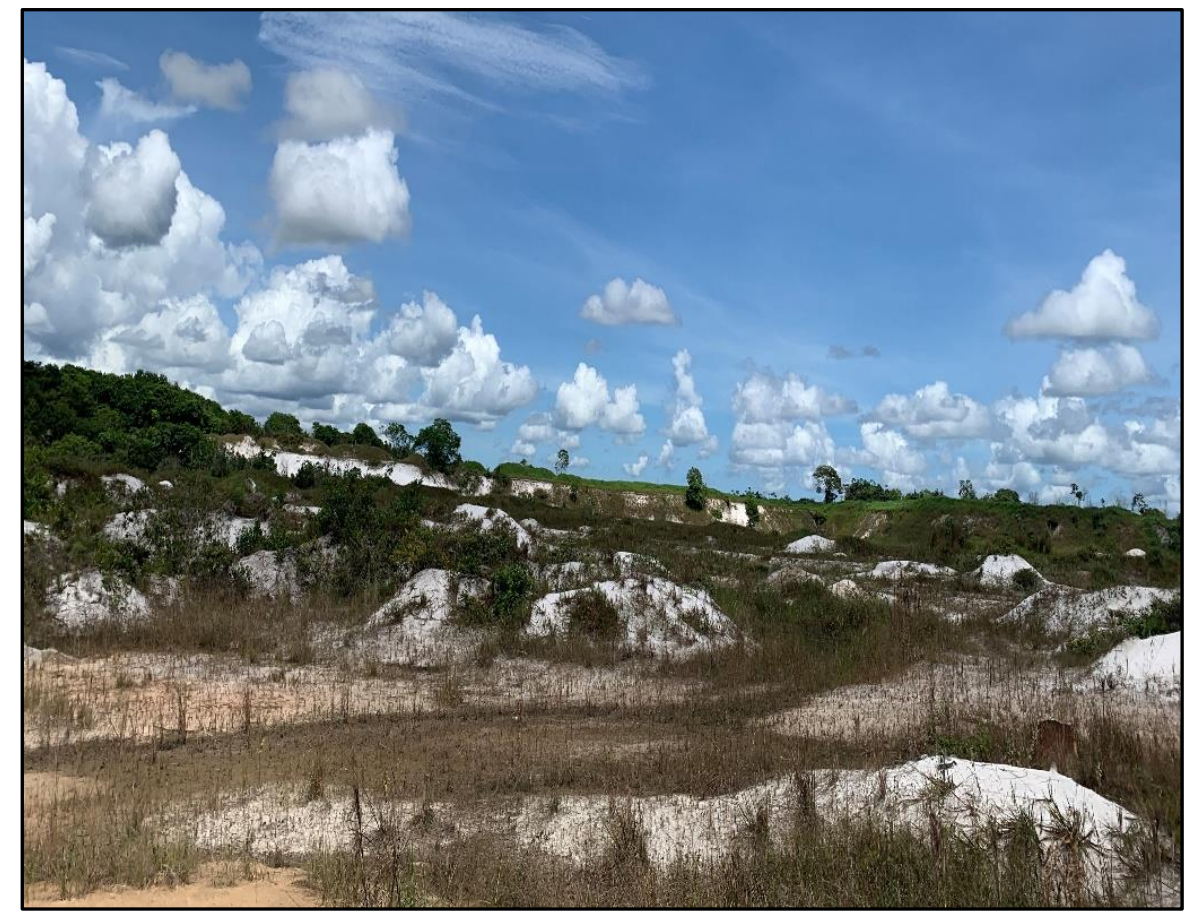

Figure 1 Abandoned sand mining area without any post-mining treatment

In Guyana, sand mining is done by the opencast method, where an excavator removes the vegetation and topsoil to access sand deposits in the ground. The sand is then loaded into trucks for transportation and trading purposes. Over time, large extents of the land become degraded and denuded of vegetative cover by the cumulative impact of mining and the associated vehicular movement. The Mining Act of 1989 is the main legislative instrument for managing mining in Guyana, with guardianship of all minerals vested to the Guyana Geology and Mines Commission (GGMC). GGMC, in partnership with the Environmental Protection Agency (EPA), drafted the Code of Practice for Sand and Loam mining in August 2010. The Code of Practice provides environmental management guidance to mining operators and advises progressive reclamation techniques such as stabilization, recontouring, and revegetation of mined-out areas as the mine progresses, but these activities are seldom done. 
Sand mining operations undoubtedly have brought Guyanese wealth and employment opportunities but simultaneously have led to extensive environmental degradation. Sand mining activities coupled with the absence of post-mining treatment and mismanagement of mined areas are making the surrounding ecosystems more vulnerable to environmental degradation, leading to large-scale land cover, land-use changes and species loss. With sand mining operators limited economic and technical resources, it is difficult to restore the environment to its former productivity levels. Therefore, a need arises to collect baseline data for documenting the status, monitoring trends, and informing policy development for reclamation efforts.

\subsection{Problem statement}

Tropical forests are increasingly subjected to a wide range of disturbances of variable duration, intensity [12], and frequency resulting in loss of species diversity and ecosystem services [13]. Land-use changes are among the most direct drivers of loss of species diversity at local and regional scales. Intensification of land use through anthropogenic activities such as sand mining is believed to alter the composition and decrease the diversity of biological communities. The Food and Agriculture Organization (FAO) and UNEP [14] alluded that "the net loss of forest area decreased from 7.8 million hectares per year in the 1990 s to 4.7 million hectares per year during 2010-2020" [14].

In Guyana, land classified as forest follows the definition outlined in the Marrakech Accords [15]. The types of forest based on this classification are Mixed forest, Montane and Steep forest, Wallaba/Dakama/Muri shrub, Swamp and Marsh forest, and Mangrove forest. FAO calculates that forested land accounts for $80 \%(18,452,160 \mathrm{ha})$ of Guyana's area $(21,497,000 \mathrm{ha})$ [16]. The estimates reported by FAO [16] are similar to those reported by Sizer [17] and Ter Steege [18], who reported that more than $80 \%$ of Guyana is covered with forest and much of this is still in a pristine state $[17,18]$. Guyana began systematically reporting forest degradation in 2010, with the total forest degradation for 20102016 being 27,903 hectares (ha). In Guyana, a key driver of forest degradation is mineral mining, particularly gold mining [19]. However, even though the perceived rate of deforestation associated with sand mining is small, the effect of land degradation is extensive, especially if extraction is done without proper post-mining treatment.

Sand mining sites are often located in areas with significant biological and environmental characteristics, such as small islands and tropical rainforests [20]. The Soesdyke-Linden Highway comprises rich natural vegetation as well as large deposits of sand. However, for the past decade, increased sand mining practices have resulted in vegetation destruction and deterioration of the environment. The natural regeneration of forests is considerably slower following disturbances that heavily impact soils and aboveground vegetation, often with long-lasting effects on species composition [12]. Moreover, the adverse impacts of sand mining activities can be quickly gauged from the denudation of the vegetation cover in the mining areas. Anthropogenic alterations of vegetation cover within the immediate landscape of the Soesdyke-Linden Highway are more intense relative to adjacent areas of the flood plains of the Demerara River. This is supported by data obtained from the Global Forest Watch (GFW), which showed that in 2010, the Soesdyke-Linden Highway (including Timehri) had 50.3kha of tree cover, extending over $86 \%$ of its land area; however, in 2020 , it lost 323ha [21].

The Soesdyke-Linden area was selected as the area of study because there have been significant disturbances due to sand mining. These disturbances are expected to increase as significant amounts of economic and associated infrastructure development are anticipated in Guyana. Moreover, the area also has multiple abandoned sandpits, which have shown evidence of ecological succession.

\subsection{Ecological Succession}

Ecological succession refers to how communities change over time and the relative role of early and late colonizing species, disturbance, and life-history characteristics in shaping the sequence of communities at a particular site [22]. Significant, low-intensity disturbances, such as sand mining, result in moderate succession, where species can live in the soil and rapidly recolonize areas after the disturbance [23]. This type of succession is called secondary succession and will be the focus of this paper. The series of successional communities can be recognized as different stages. Each stage is treated as an existing vegetation type once the structure and composition of the stage reach a relatively stable state [24]. Even though secondary succession has been studied for many decades, approaches have become more sophisticated, and researchers continue to explore the commonalities and variances between plant community assembly and development.

Succession is a central theory in community ecology that seeks to understand how and why species' abundances change after a severe disturbance [25]. However, the study of secondary succession has changed dramatically since it became a core subject in ecology. Succession was perceived as an ordered process with a predictable species turnover and a clear and predetermined endpoint [26, 27]. However, it is now understood as a complex interplay between predictable 
and unpredictable processes. While the changes of specific community properties are relatively predictable over time, other community properties do not change predictably over time [28, 29].

Today, improving many aspects of successional theory is important because we need to understand the main drivers behind forest recovery in abandoned lands that have been subjected to disturbances. However, we do not fully understand how several drivers affect the regeneration of early secondary tropical forests and its consequences on tropical forest community assembly. While describing successional stages is an important endeavor, forest recovery after severe disturbances in tropical landscapes is patchy and idiosyncratic among forest stands across the landscape $[30,31]$. This is reflected in the unpredictability of the rates of change that different community properties experience over time after a severe disturbance [32]. Understanding the variability of successional trajectories is vital because it helps us identify causal relationships between biotic or abiotic variables and trajectory variability and can shed light on which drivers and mechanisms might be responsible for the observed trajectories [33, 34].

\section{Material and methods}

\subsection{Study Area}

This study was conducted along the Soesdyke-Linden Highway (Figure 2), which is situated along the Demerara River $\left(6.34630^{\circ},-58.21502^{\circ}\right)$ within the lowland region of undulating land, covering most of Guyana's northern and central parts, generally with an elevation below $50 \mathrm{~m}$.

The dominant soil type within the study area is albic Arenosols (bleached white sands), which is permeable and low in nutrients. According to Ter Steege, et al. [35], the area of study lies within the White Sands Formation (GuyanaSuriname-French Guiana) and is categorized by dry evergreen forest dominated by Dimorphandra conjugata (Dakama Forest). This forest is characterized by a very high standing litter crop and is very fire-prone. In areas of the SoesdykeLinden Highway where fires are very regular, Dakama Forest degrades into Muri-scrub and finally into unproductive grassland [36].

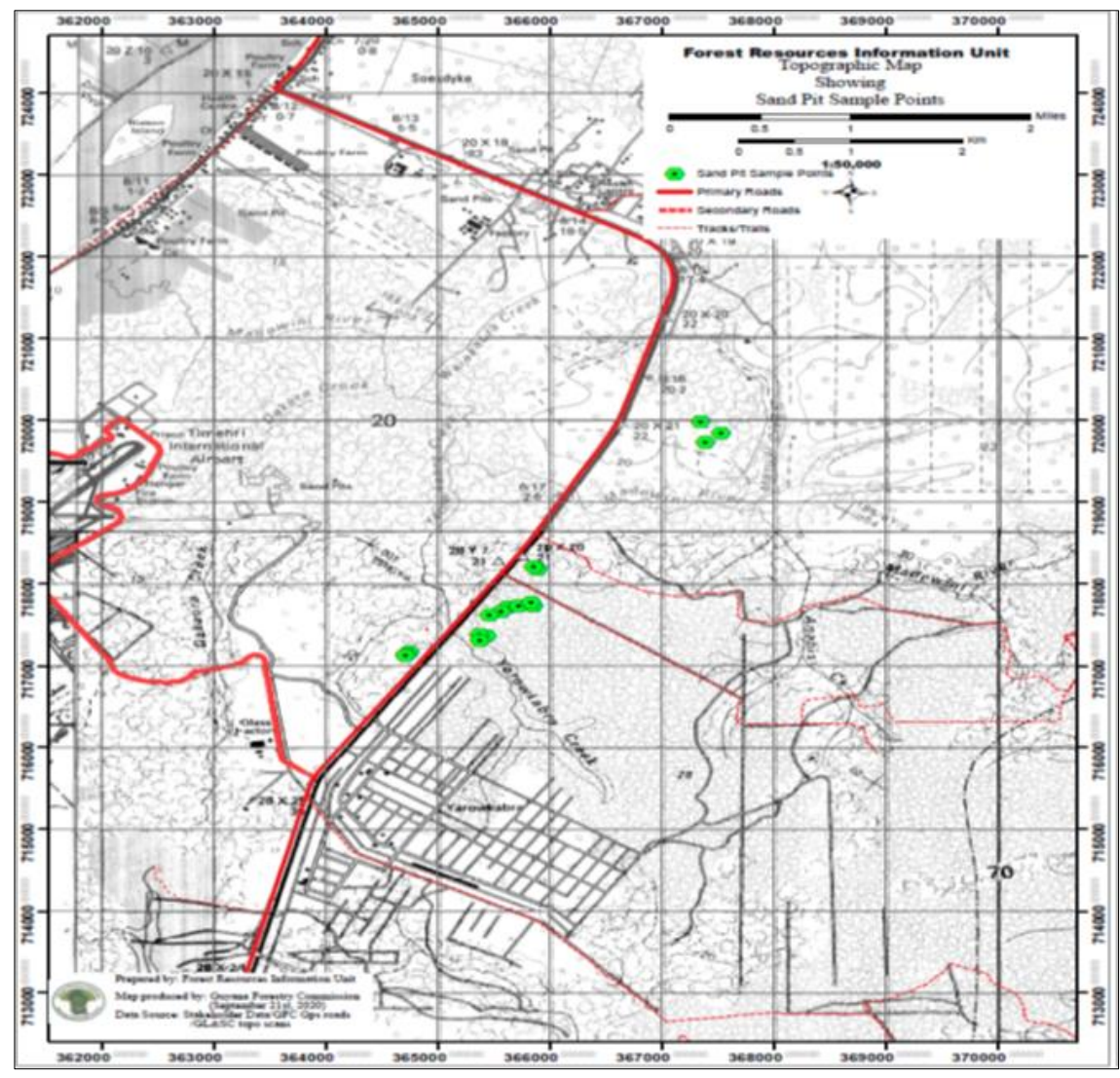

Figure 2 Map of the area where sample plots were located 


\subsection{Data Collection}

Data collection was carried between the $1^{\text {st }}$ to the $18^{\text {th }}$ of September 2020 . The research design methodology included collecting qualitative data from semi-structured interviews and quantitative data via the conduct of forest field inventories.

Interviews were conducted with regulatory officers and sand mining operators on the principal parameter of investigating secondary succession of woody plants on abandoned sand mining areas along the Soesdyke-Linden Highway. Interviews were done to determine the time since the last disturbance (fallow time) and the magnitude of disturbance before the abandonment of the mining area.

While the preferred manner of studying temporal change is long-term research, we typically lack the time and resources to describe the characteristic regeneration of a given area. Thus, we use space-for-time substitution to achieve sufficient temporal scope over a limited study period [37,38]. Specifically, we treat areas abandoned at different times as an ordered chronosequence. This study used space-for-time substitution to study successional trajectories. The sand mining areas abandoned at different times within the study area were treated as a homogeneous chronosequence. Chronosequences and associated space-for-time substitution represent a type of 'natural experiment' [37, 39] and are the most frequently used indirect approaches for measuring temporal dynamics.

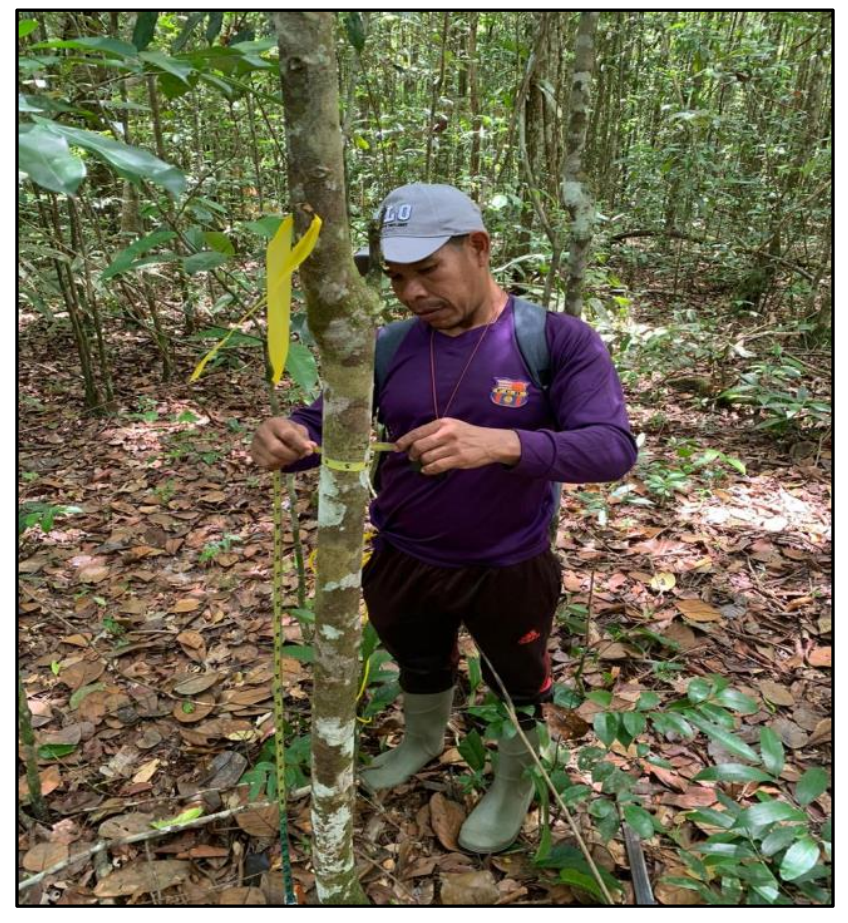

Figure 3 Forestry assistant measuring DBH

Accordingly, for this study, the following sample sites were recognized as different stages of the chronosequence:

- Site C1 - an area that the disturbance of sand mining has impacted, but no disturbances have occurred within the three years.

- Site C2 - an area that the disturbance of sand mining has impacted, but no disturbances have occurred within the last five years.

- $\quad$ Site C3 - an area that the disturbance of sand mining has impacted, but no disturbances have occurred within the last ten years.

- $\quad$ Site C5 - an area that the disturbance of sand mining has impacted, but no disturbances have occurred within the fifteen years

- Site CU - an area that has not been impacted by any disturbances and represents the natural forest composition.

A forest inventory (Figure 3) was conducted utilizing transects that extended the diameter of the sample sites containing squared plots measuring $10 \mathrm{~m}$ x $10 \mathrm{~m}$ each. Stratified random sampling techniques were employed where a total of 
fifteen (15) $10 \mathrm{~m} \times 10 \mathrm{~m}$ plots were sampled for woody plants $>2.5 \mathrm{~cm}$ dbh, and a $1 \mathrm{~m} \times 1 \mathrm{~m}$ subplot was randomly sampled from each plot for seedlings $<2.5 \mathrm{~cm} \mathrm{dbh}$.

With the assistance of a local forester and a forestry assistant, all woody plants were identified using local names and collection numbers, and their diameter at breast height (DBH) was recorded.

\subsection{Data analysis}

The inventory of woody plants established phytosociological and diversity parameters [40]. Phytosociological parameters provide information about community structure. The floristic structure was assessed quantitatively by calculating the Importance Value Index (IVI) for each species. The Importance Value Index (IVI) of Mueller-Dombois and Ellenberg [40] was used to describe and compare the species dominant in sample sites. The species with the highest IVI was considered to be the most "important" in a plot. This index is used to determine the overall importance of each species in the community structure. The IVI represents the sum of the values for relative density (RD), relative frequency (RF), and relative dominance (RDo), and its value varies from 0 to 300 . The IVI was calculated to rank species contribution to community composition [41]. The species having the highest IVI is considered the most dominant in the community [42].

In addition to the phytosociological variables, floristic diversity indices such as the Shannon Wiener Index ( $\left.\mathrm{H}^{\prime}\right)$ and the Simpson Index were calculated. Species diversity is a crucial component of any analysis of natural communities and ecosystems. It consists of two components; richness, which is the number of species occurring at a community or ecosystem level, and evenness, which reflects the degree of dominance of the most common species in the community. Consequently, greater diversity comes from a larger number of species and greater evenness in species' relative abundance.

Simpson's Diversity Index considers the number of species present, as well as the relative abundance of each species [43]. As species richness and evenness increase, so diversity increases. Moreover, Shannon-Weiner Index assumes that individuals are randomly sampled from a large independent population, and all the species are represented in the sample [44]. Both indices were calculated using the diversity function in the PAST Version 4.03 software package.

\section{Results}

\subsection{Semi-structured Interviews}

There is a total of seventy-three (73) sand mining areas along the Soesdyke-Linden Highway where $44 \%$ are active, $48 \%$ applications are pending approval, and $8 \%$ which status is unknown (Figure 4). Given that a significant amount of application is pending approval, it can be ascertained that sand mining activities are expected to increase within the study area.

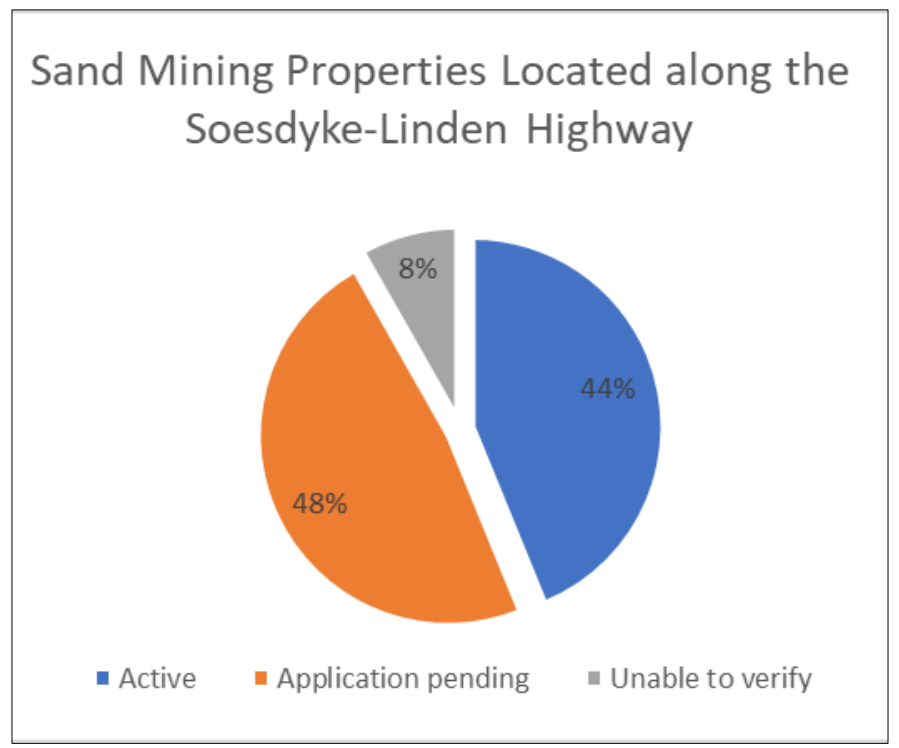

Figure 4 Status of sand mining operations on the Soesdyke-Linden Highway (Source: GGMC, 2020) 
It was observed within the study area that many sand mining operations were carried out in the absence of post-mining treatment and management of the mined areas, leaving behind abandoned sandpits, causing massive damage to the landscape and biological communities.

Further, interviews with sand mining operators revealed that post-mining treatment varied with operators and heavily depended on the land's intended use post sand mining. The operators alluded to the storage of topsoil, which was referred to as "grey sand," and its placement post-mining to allow for the natural regeneration of native species. However, based on observations, storage of topsoil was seldom done. When asked about their perceived state of vegetation post sand mining, the operators generally observed that the vegetation rarely returned to its original state. Notwithstanding, based on feedback received, we were able to identify sample plots of varying ages post sand mining.

\subsection{Inventory of woody plants}

A total of five (5) sites were sampled, which included areas of varying successional years and an undisturbed area. A total of 241 plants were recorded, encompassing 22 species across 16 Families (Table 1). The most abundant family was Anacardiaceae, followed by Fabaceae.

Table 1 Species and Families of woody plants identified

\begin{tabular}{|c|c|c|c|}
\hline No. & Common Name & Scientific Name & Family \\
\hline 1 & Acacia & Acacia mangium & Fabaceae \\
\hline 2 & Awara & Astrocaryum vulgare & Arecaceae \\
\hline 3 & Awati & Maprounea guianensis & Euphorbiaceae \\
\hline 4 & Barataballi & Chrysophyllum sanguinolentum & Sapotaceae \\
\hline 5 & Blood wood & Vismia macropylla & Guttifeae \\
\hline 6 & Congo pump & Cecropia obtusa & Cercropiaceae \\
\hline 7 & Dakama & Dimorphandra conjugata & Fabaceae \\
\hline 8 & Duka & Tapiria marchandii & Anacardiaceae \\
\hline 9 & Guava skin kakaralli & Escheweilera alata & Lecythidaceae \\
\hline 10 & Kabukalli & Goupia glabra & Celastraceae \\
\hline 11 & Kaditiri & Sclerolobium guianense & Fabaceae \\
\hline 12 & Karishiri & Oxandra asbeckii & Annonaceae \\
\hline 13 & Kereti Silverballi & Ocotea puberula & Lauraceae \\
\hline 14 & Korokororo & Ormosia coutinhoi & Fabaceae \\
\hline 15 & Marishiballi & Licania cf. micrantha & Chrysobalanaceae \\
\hline 16 & Pawpaw & Asimina triloba & Annonaceae \\
\hline 17 & Sand Baromalli & Catostemma commune & Bombacaceae \\
\hline 18 & Buck Cashew & Anacaedium Occidentale & Anacardiaceae \\
\hline 19 & Shibidan & Aspidosperma album & Apocynaceae \\
\hline 20 & Soft Wallaba & Eperua falcata & Fabaceae \\
\hline 21 & Wina Kakaralli & Lecythis corrugata & Lecythidaceae \\
\hline 22 & Tabaniro & Humiria balsamifera & Humiriaceae \\
\hline
\end{tabular}

\subsection{Environmental Characteristics and Phytosociological Parameters}

Site C1 was an area that the disturbance of sand mining has impacted, but no disturbances have occurred within the last three years. This site can be described as an extreme forest with extensive secondary vegetation consisting of few 
primary species. It comprised of seasonal swamps (inundated area) and elevated hilltops; however, the inundated portion of the plot was reduced due to low water levels in nearby creeks. The type of soil was white sand, and the terrain was slightly undulating with a 10 -meter average elevation. The site consisted of an open limited canopy cover with gaps generally less than $10 \%$ and canopy height ranged from 5- 15 meters. The understory vegetation ranged from sparse to dense according to disturbance level, and the leaf litter layer persisted.

Table 2 summarises the phytosociological parameters of the woody plants sampled at a site-C1 disturbed three (3) years post-mining. For this site, a total of 23 plants accounting for 7 species were sampled. Dominant species include bloodwood (Vismia macropylla) and acacia (Acacia mangium), which accounted for $34.8 \%$ and $21.7 \%$, respectively. However, Acacia mangium had a higher relative dominance than Vismia macropylla because the Acacia mangium plants were more mature and had a higher basal area than that of Vismia macropylla. The Vismia macropylla plants were sampled in the sub-plot and were essentially seedlings with a DBH less than $2.5 \mathrm{~cm}$. Consequently, for the youngest chronosequence of 3 years, Acacia mangium had the highest IVI of 112 for the site.

Table 2 Phytosociological parameters of woody plants sampled at site disturbed three (3) years post sand mining

\begin{tabular}{|l|c|c|l|l|l|c|}
\hline Species & Occurrence & Number of plants & Rdo & Rf & RD & IVI \\
\hline Acacia mangium & 2 & 5. & 70.26 & 20 & 21.74 & 112.00 \\
\hline Vismia macropylla & 2 & 8 & 10.24 & 20 & 34.78 & 65.02 \\
\hline Cecropia obtusa & 1 & 1 & 1.11 & 10 & 4.35 & 15.45 \\
\hline Dimorphandra conjugata & 1 & 1 & 2.49 & 10 & 4.35 & 16.84 \\
\hline Oxandra asbeckii & 2 & 3 & 2.49 & 20 & 13.04 & 35.53 \\
\hline Asimina triloba & 1 & 1 & 8.99 & 10 & 4.35 & 23.34 \\
\hline Trattinnickia burserifolia & 1 & 4 & 4.43 & 10 & 17.39 & 31.82 \\
\hline Total & 10 & 23 & 100 & 100 & 100 & 300 \\
\hline
\end{tabular}

Site C2 was also an extreme forest with extensive secondary vegetation with a few primary species. It included seasonal swamps (inundated area) and elevated hilltops, with the inundated portion being slightly less due to reduced water levels in nearby creeks. The type of soil was white sand with a few patches of brown sand. The terrain was relatively flat to undulating with a 10-meter average elevation. The site was open with limited canopy cover. Gaps in the canopy were generally less than 30\%, and canopy height ranged from 15-25 meters. The understory vegetation ranged from sparse to dense according to disturbance level. The leaf litter layer persisted. The human modification included bulldozed areas and roads to access sandpits.

Table 3 Phytosociological parameters of woody plants sampled at site disturbed Five (5) years post sand mining

\begin{tabular}{|l|c|c|c|c|c|c|}
\hline Species & Occurrence & Number of plants & Rdo & Rf & RD & IVI \\
\hline Acacia mangium & 1 & 1 & 2.82 & 9.09 & 2.38 & 14.30 \\
\hline Maprounea guianensis & 2 & 3 & 1.41 & 18.18 & 7.14 & 26.74 \\
\hline Vismia macropylla & 3 & 10 & 7.43 & 27.27 & 23.81 & 58.51 \\
\hline Cecropia obtusa & 1 & 10 & 14.80 & 9.09 & 23.81 & 47.70 \\
\hline Tapiria marchandii & 1 & 14 & 70.46 & 9.09 & 33.33 & 112.88 \\
\hline Goupia glabra & 1 & 1 & 0.11 & 9.09 & 2.38 & 11.58 \\
\hline Oxandra asbeckii & 1 & 2 & 0.14 & 9.09 & 4.76 & 13.99 \\
\hline Asimina triloba & 1 & 1 & 2.82 & 9.09 & 2.38 & 14.30 \\
\hline Total & 11 & 42 & 100 & 100 & 100 & 300 \\
\hline
\end{tabular}


A total of 42 plants were sampled in Site C2, accounting for 8 species (Table 3). Duka (Tapiria marchandii), congo pump (Cecropia obtuse), and bloodwood (Vismia macropylla) were the dominant species which accounted for 33.3\%, 23.8\%, and $23.8 \%$ respectively of the total plants sampled. Tapiria marchandii had the highest basal area, resulting in it having the highest relative dominance, followed by Cecropia obtuse and Vismia macropylla. Tapiria marchandii also possessed the highest relative frequency and relative density resulting in it having the highest IVI of 112.88 for the chronosequence of 5 years.

Site C3 consisted of a prevalent mixed forest on sandy soil with an average elevation of $10 \mathrm{~m}$. The forest had an uneven, sparse canopy, and windfall naturally created canopy gaps. Forest height ranged from 20-40 m with a few emerging species. Lianas were rare, with no canopy infestation. However, frequent epiphytes and hemi-epiphytes were observed.

A total of 54 plants were sampled in Site 3, accounting for 5 species (Table 4). Duka (Tapiria marchandii) and Dakama (Dimorphandra conjugata) were the dominant species, accounting for $48.1 \%$ and $27.8 \%$ of the total plants sampled. Tapiria marchandii had the highest basal area, resulting in it having the highest relative dominance, followed by Dimorphandra conjugata. Tapiria marchandii also possessed the highest relative frequency and relative density resulting in it having the highest IVI of 154.51 for the chronosequence of 10 years.

Table 4 Phytosociological parameters of woody plants sampled at site disturbed ten (10) years post sand mining.

\begin{tabular}{|l|c|c|c|l|l|l|}
\hline Species & Occurrence & Number of plants & Rdo & Rf & RD & IVI \\
\hline Vismia macropylla & 2 & 8 & 3.89 & 25.00 & 14.81 & 43.70 \\
\hline Emmotum fagifolium & 1 & 1 & 0.03 & 12.50 & 1.85 & 14.39 \\
\hline Cecropia obtusa & 1 & 4 & 13.33 & 12.50 & 7.41 & 33.23 \\
\hline Dimorphandra conjugata & 1 & 15 & 13.89 & 12.50 & 27.78 & 54.17 \\
\hline Tapiria marchandii & 3 & 26 & 68.86 & 37.50 & 48.15 & 154.51 \\
\hline Total & 8 & 54 & 100 & 100 & 100 & 300 \\
\hline
\end{tabular}

Site C4 consisted of a predominant mixed forest on white sand soil with an average $10 \mathrm{~m}$ elevation. The forest canopy was moderately open and high. Tree heights ranged from $15-30 \mathrm{~m}$, and lianas were occasional, not creating a canopy infestation. Moreover, the understory vegetation ranged from sparse to dense according to the disturbance level.

A total of 92 plants were sampled in Site C4, accounting for 4 species (Table 5). Dominant species were Duka (Tapiria marchandii), which accounted for $78.9 \%$ of the total plants sampled for site 3. Tapiria marchandii plants had the highest basal area, resulting in the highest relative dominance followed by Dimorphandra conjugata. Tapiria marchandii also possessed the highest relative frequency and relative density resulting in it having the highest IVI of 215.42 for the chronosequence of 15 years.

Table 5 Phytosociological parameters of woody plants sampled at site disturbed fifteen (15) years post sand mining

\begin{tabular}{|l|c|c|c|c|c|c|}
\hline Species & Occurrence & Number of plants & Rdo & Rf & RD & IVI \\
\hline Vismia macropylla & 1 & 11 & 1.67 & 14.29 & 12.36 & 28.31 \\
\hline Cecropia obtusa & 1 & 1 & 2.03 & 14.29 & 1.12 & 17.44 \\
\hline Dimorphandra conjugata & 2 & 7 & 2.40 & 28.57 & 7.87 & 38.83 \\
\hline Tapiria marchandii & 3 & 70 & 93.91 & 42.86 & 78.65 & 215.42 \\
\hline Total & 7 & 89 & 100 & 100 & 100 & 300 \\
\hline
\end{tabular}

Site $\mathrm{CU}$, the control plot, consisted of a mixed forest on white sand that occurred on a slightly undulating terrain. The height of the canopy was approximately 12-30 meters, and the diameter was 0.6-0.7 meters. Soft wallaba (Eperua falcata) and Wina (Lecythis corrugata) were the dominant species. 
A total of 33 plants were sampled in Site CU accounting for 13 different species (Table 6). The most dominant species was Eperua falcata which accounted for $27.3 \%$ of the total plants sampled for site 5. Eperua falcata plants had the highest basal area, which resulted in it having the highest relative dominance. Eperua falcata also possessed the highest relative frequency and relative density, thus having the highest IVI of 64.76 for the controlled site.

Table 6 Phytosociological parameters of woody plants sampled at the control site

\begin{tabular}{|l|c|c|c|c|c|c|}
\hline Species & Occurrence & Number of plants & Rdo & Rf & RD & IVI \\
\hline Astrocaryum vulgare & 1 & 1 & 1.05 & 5.56 & 3.03 & 9.63 \\
\hline Chrysophyllum sanguinolentum & 2 & 3 & 0.16 & 11.11 & 9.09 & 20.36 \\
\hline Vismia macropylla & 1 & 1 & 30.49 & 5.56 & 3.03 & 39.07 \\
\hline Tapiria marchandii & 2 & 3 & 3.60 & 11.11 & 9.09 & 23.80 \\
\hline Escheweilera alata & 1 & 1 & 7.62 & 5.56 & 3.03 & 16.21 \\
\hline Sclerolobium guianense & 1 & 2 & 2.69 & 5.56 & 6.06 & 14.30 \\
\hline Ocotea puberula & 1 & 1 & 1.27 & 5.56 & 3.03 & 9.85 \\
\hline Ormosia coutinhoi & 1 & 3 & 0.23 & 5.56 & 9.09 & 14.88 \\
\hline Licania cf. micrantha & 2 & 2 & 0.04 & 11.11 & 6.06 & 17.21 \\
\hline Catostemma commune & 1 & 1 & 17.58 & 5.56 & 3.03 & 26.16 \\
\hline Aspidosperma album & 1 & 1 & 1.27 & 5.56 & 3.03 & 9.85 \\
\hline Eperua falcata & 2 & 9 & 26.38 & 11.11 & 27.27 & 64.76 \\
\hline Lecythis corrugata & 2 & 5 & 7.65 & 11.11 & 15.15 & 33.91 \\
\hline Total & 18 & 33 & 100 & 100 & 100 & 300 \\
\hline
\end{tabular}

\subsection{Species Diversity}

Species diversity is an important indicator that reflects the effect of secondary forest restoration in tropical regions [23]. The chronosequence of 3 years had the highest species diversity for the disturbed sites, and the undisturbed site had the highest species diversity overall for both the Simpson and Shannon Weiner diversity indices. A clear trend was observed where species diversity decreased as the age of the sample sites increased (Table 7).

Table 7 Species diversity indices calculated for the various sample sites

\begin{tabular}{|l|l|c|c|c|c|}
\hline \multirow{2}{*}{ Diversity Index } & \multicolumn{5}{|c|}{ Chronosequence } \\
\cline { 2 - 6 } & \multicolumn{1}{|c|}{$\mathbf{3}$ Yrs } & 5 Yrs & 10 Yrs & 15 Yrs & Undisturbed \\
\hline Simpson_1-D & $0.597( \pm 0.081)$ & $0.57( \pm 0.184)$ & $0.53( \pm 0.071)$ & $0.33( \pm 0.2)$ & $0.69( \pm 0.242)$ \\
\hline Shannon_H & $1.04( \pm 0.19)$ & $1.05( \pm 0.398)$ & $0.85( \pm 0.181)$ & $0.51( \pm 0.227)$ & $1.46( \pm 0.744)$ \\
\hline
\end{tabular}

\section{Discussion}

Even though sand mining positively impacts Guyana's local economy, the extraction of sand in commercial quantities can lead to various changes to the natural environment. Opencast sand mining is a major cause of ecological disturbances due to land degradation and related changes in the structural and functional physiognomies of the native vegetation. Sand mining disrupts the natural ecosystem through the removal of topsoil and vegetation. The natural landscape of the Soesdyke-Linden Highway is historically known for sand mining. Current and historic human activities within the landscape have substantially modified the habitats' primary ecological functions and species composition, resulting in habitat loss and species displacement. The goals of successional ecology are to describe the similarities and differences in both the pattern and the process, extract generalizations, and identify the basis for differences in the process. Patterns of successional change can be asserted to some degree and at some scale for almost any natural system 
[30]. However, individual successional processes appear to be unique and dependent on timing, initial conditions, and other factors.

Secondary succession occurs in areas where disturbances have not been so intense as to eliminate the regenerative capacity of the vegetation. In this study, the abundance of woody plants increased throughout the chronosequence of the disturbed sites, whereas the heterogeneity declined, reflecting a decrease in species diversity. Tapiria marchandii of the family Anacardiaceae dominated the 5, 10, and 15 years plots and exhibited the highest IVIs in those plots, respectively (Figure 5). It can be inferred that the dominance of Tapiria marchandii may be due in part to competition that is known to influence the trajectory of secondary succession. Connell and Slatyer [23] proposed tolerance as a primary driver of succession, which is a competitive mechanism because the only species able to persist as succession progresses are those able to withstand low resource levels and outcompete other species [23]. As time progresses during succession, competition intensifies because resources such as sunlight and soil nutrients become scarcer [45, 46].

Woody plants such as Tapiria marchandii can maximize biomass allocation at the top of the canopy, become dominants for many years, and even delay species turnover. Tapiria marchandii had high densities and dominated the plant canopy in the chronosequences of 5, 10, and 15 years, which could have precluded the establishment and growth of other species [47]. Consequently, it can be said that Tapiria marchandii was well adapted to the environmental conditions post sand mining in the study area. Competition can be very intense early in succession, mainly because plants maximize biomass allocation to intercept light. Woody plants such as Tapiria marchandii, which can recruit abundantly during the first years of succession and dominate the canopy, tend to modulate the trajectories of different community properties for decades, thereby asserting their importance.

Fabaceae was the second most abundant family identified during the forest inventory. Dimorphandra conjugata of the family Fabaceae also adapted well to the conditions post sand mining in the chronosequence of 10 and 15 years. Fabaceae species are dominant during early secondary succession because the species in this family tend to have mechanisms to counteract the harsh conditions of early successional stages. These pioneer species sometimes function as nurse plants for seedlings but also competes with established plants for resources. Eperua falcata, also of the family Fabacea dominated the undisturbed plot with the highest IVI of 64.76. This clearly shows that species from the Fabaceae family are well adapted to disturbed and undisturbed sites within the study area; making them a great candidate for assisted regeneration efforts.

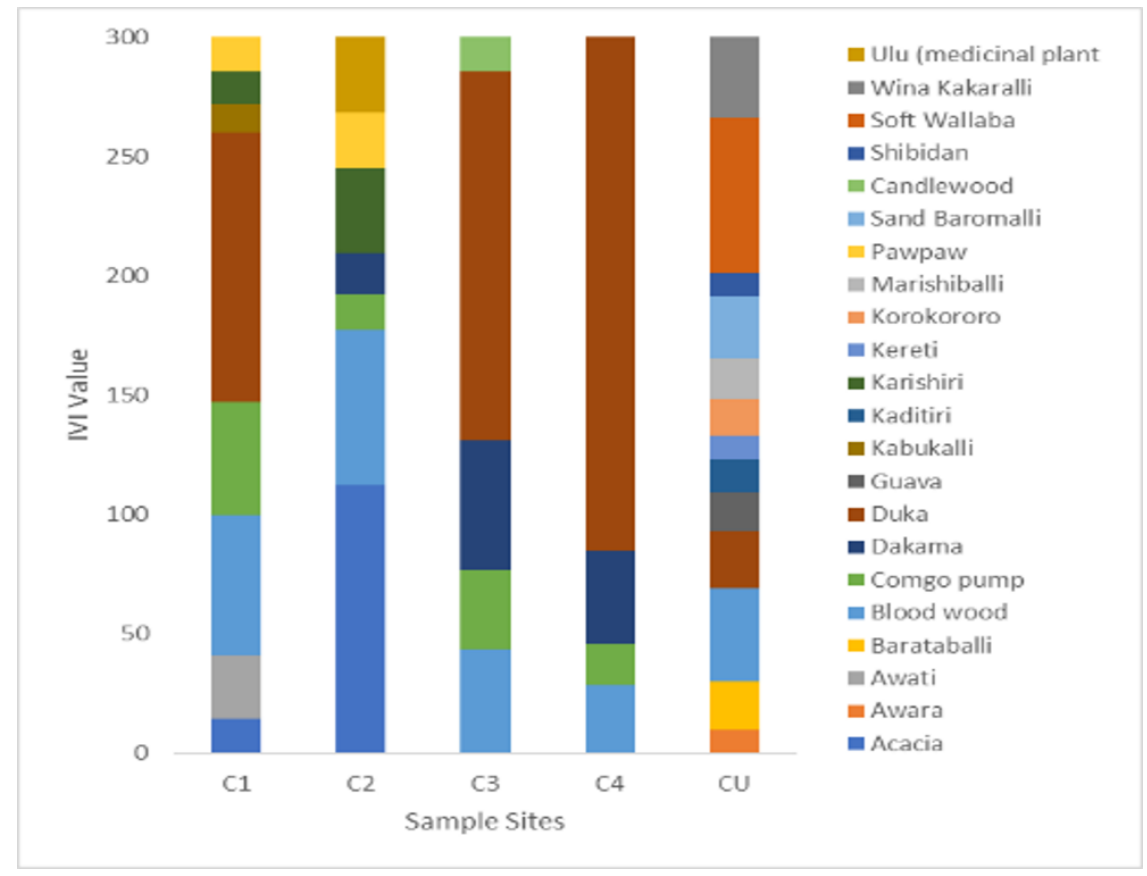

Figure 5 Distribution of the Importance Value Index for the disturbed and undisturbed sites sampled

Anthropogenic disturbances caused due to mining produces shifts in the structure and richness of the vegetation of the native species, which dominate the ecosystem [48]. Some researchers have predicted that diversity might decrease during a successional sequence [49, 50]. For example, Habeck [51], found that diversity steadily decreased after initial 
postfire establishment in cedar-hemlock forests in the Northern Rocky Mountains. In the case of this current study, it was observed that species diversity for both Simpson and Shanon weiner index decreased as successional age increased. The site of 3 years post-disturbance had the highest species diversity of the disturbed sites which constantly decreased along the chronosequence of 5, 10 and 15 years. However, the undisturbed site exhibited the highest species richness and evenness, which was evident as it had the highest species diversity for both diversity indices. In early successional plots, species diversity tends to be high because various species are competing for limited resources. Only species well adapted to site conditions post sand mining can proliferate and essentially dominate plots over time. This was observed in the disturbed plots where the number of plants and biomass increased as successional age increased. However, dominance over time results in a decrease in species diversity over time and can be seen in the species diversity distribution chart in Figure 6.

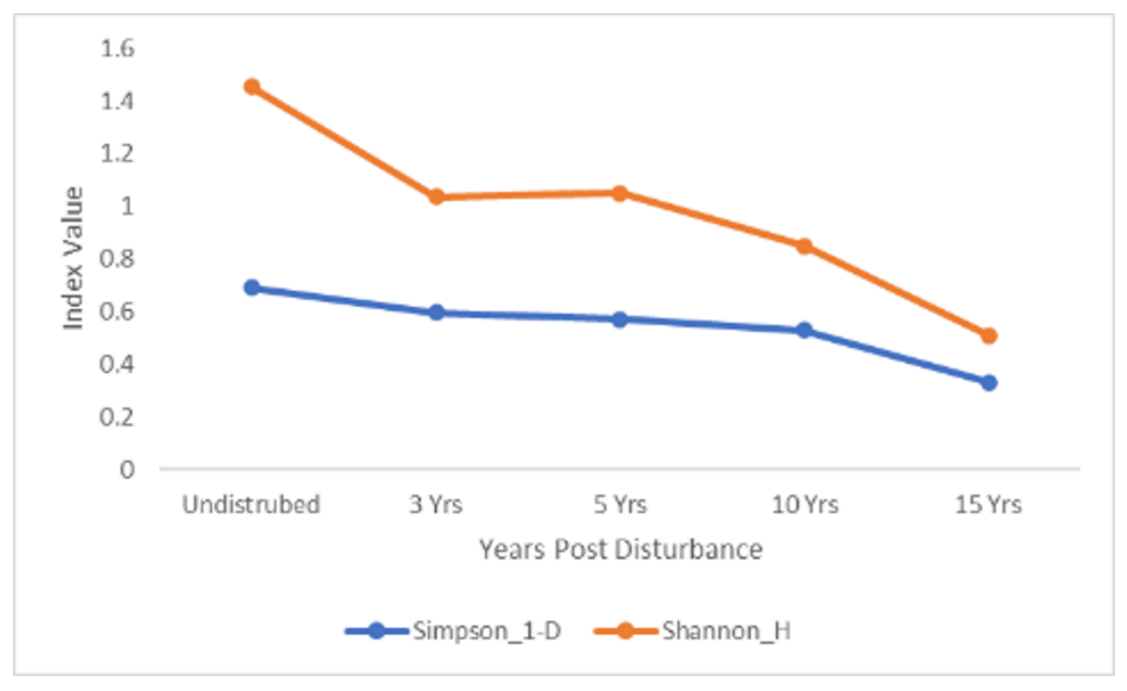

Figure 6 Species diversity distribution for sites sampled along the study area

\section{Conclusion}

The results of this study showed that there are both short term and long-term negative impacts on the vegetation in sand mining areas on the Soesdyke-Linden Highway area; and also highlighted the need to regulate sand mining activities to avoid further damage to the vegetation and the rest of the environment.

The exposure of locations on the Soesdyke-Linden Highway to sand mining activities, is responsible for the major vegetation changes occurring within the area. The long-term impacts of such activities will increase the vulnerability of such sites to the severity of even more frequent loss in both plant species and plant abundance, which in time will most likely increase in magnitude.

Therefore, in recognising the impact of this dominant economic activity on the flora environment, it is important that more careful monitoring and enforcement measures be put in place to mitigate the current negative impacts. It is also recommended that future research be conducted to investigate the impact sand mining activities may have on the faunal diversity within the study area.

\section{Compliance with ethical standards}

\section{Acknowledgments}

The author would like to express gratitude to Mr. Phillip Da Silva from the Faculty of Natural Sciences, University of Guyana (Tain Campus) and Mr. Owen Bovell from the Faculty of Agriculture and Forestry, University of Guyana (Turkeyen Campus) for their technical guidance.

\section{Disclosure of conflict of interest}

The author declares there are no conflicts of interest. 


\section{References}

[1] UNEP. The Search for Sustainable Sand Extraction Is Beginning [Internet]. (c) 2019 [cited 2021 March 26]. Available from https://www.unep.org/news-and-stories/story/search-sustainable-sand-extraction-beginning.

[2] Peduzzi P. Sand rarer than one thinks. Environmental Development. 2014; 11: 208-18.

[3] Farahani H, Bayazidi S. Modeling the assessment of socio-economical and environmental impacts of sand mining on local communities: A case study of Villages Tatao River Bank in North-western part of Iran. Resources Policy. 1 Mar 2018; 55: 87-95.

[4] Koehnken L, Rintoul MS, Goichot M, Tickner D, Loftus AC, Acreman MC. Impacts of riverine sand mining on freshwater ecosystems: A review of the scientific evidence and guidance for future research. River Research and Applications. Mar 2020; 36(3): 362-70.

[5] Leal Filho W, Hunt J, Lingos A, Platje J, Vieira LW, Will M, Gavriletea MD. The Unsustainable Use of Sand: Reporting on a Global Problem. Sustainability. Jan 2021; 13(6): 33-56.

[6] John E. The impacts of sand mining in Kallada river (Pathanapuram Taluk), Kerala. J. Basic Appl. Biol. 2009; 3:10813.

[7] Gallagher L, Peduzzi P. Sand and sustainability: Finding new solutions for environmental governance of global sand resources. Geneva: United Nations Environment Programme. 2019.

[8] United Nations, Department of Economic and Social Affairs, Population Division. World Population Prospects: The 2019 Revision. 2019.

[9] CEPAL N. Economic Survey of Latin America and the Caribbean 2019. The new global financial context: effects and transmission mechanisms in the region. ECLAC. 31 Jul 2019.

[10] Ministry of Finance. Public Debt Annual Report. Government of the Cooperative Republic of Guyana. 2020.

[11] Chow MJ. Guyana: Housing Market and Implications for Macroprudential Policies. International Monetary Fund. 31 Jan 2020.

[12] Chazdon RL. Tropical forest recovery: legacies of human impact and natural disturbances. Perspectives in Plant Ecology, evolution and systematics. 1 Jan 2003; 6(1-2): 51-71.

[13] Chapman CA, Chapman LJ. Forest restoration in abandoned agricultural land: a case study from East Africa. Conservation Biology. Dec 1999; 13(6): 1301-11.

[14] FAO and UNEP. The State of the World's Forests 2020. Forests, biodiversity and people. Rome. 2020.

[15] UNFCCC. The Marrakesh Accords \& The Marrakesh Declaration [Internet]. (c) 2001 [cited 2021 July 20]. Available from: https://unfccc.int/cop7/documents/accords draft.pdf

[16] FAO. Country Profile - Guyana [Internet]. [cited 2021 May 12]. Available from http://www.fao.org/countryprofiles/index/en/?iso3=GUY.

[17] Sizer N. Profit without plunder. World Resources Institute. 9 Jan 1996.

[18] Ter Steege H. Plant diversity in Guyana: with recommendations for a national protected area strategy. 2000.

[19] Benn V, Pham TT, Moeliono M, Maharani C, Thomas R, Chesney P, Dwisatrio B, Ha CN. The context of REDD+ in Guyana: Drivers, agents and institutions. CIFOR. 28 May 2020.

[20] Ashraf MA, Maah MJ, Yusoff I, Wajid A, Mahmood K. Sand mining effects, causes and concerns: A case study from Bestari Jaya, Selangor, Peninsular Malaysia. Scientific Research and Essays. 31 Mar 2011; 6(6): 1216-31.

[21] Global Forest Watch. Tree cover in Soesdyke-Linden highway (including Timehri), Demerara-Mahaica, Guyana [Internet]. (c) $2021 \quad$ [cited 2021 July 21]. Available from https://www.globalforestwatch.org/dashboards/country/GUY.

[22] Pandolfi JM. Succession. Encyclopedia of Ecology. 2008; 3416-3424.

[23] Connell JH, Slatyer RO. Mechanisms of succession in natural communities and their role in community stability and organization. The american naturalist. 1 Nov 1977 ; 111(982): 1119-44.

[24] The Nature Conservancy. Field Methods for vegetation mapping. NBS/NPS Vegetation. 1994. 
[25] Begon M, Townsend CR, Harper JL. Ecology-From individuals to Ecosystems. John Wiley \& Sons. 2006.

[26] Clements FE. Plant succession: an analysis of the development of vegetation. Carnegie Institution of Washington. 1916.

[27] Odum EP. The Strategy of Ecosystem Development: An understanding of ecological succession provides a basis for resolving man's conflict with nature. science. 18 Apr 1969; 164(3877): 262-70.

[28] Gleason HA. The individualistic concept of the plant association. Bulletin of the Torrey botanical club. 1926; 1: 726.

[29] Arroyo-Rodríguez V, Melo FP, Martínez-Ramos M, Bongers F, Chazdon RL, Meave JA, Norden N, Santos BA, Leal IR, Tabarelli M. Multiple successional pathways in human-modified tropical landscapes: new insights from forest succession, forest fragmentation and landscape ecology research. Biological Reviews. 2017 Feb; 92(1): 326-40.

[30] Andersen DJ. Community ecology: pattern and process. Community ecology: pattern and process. 1 Jan 1986; 269-285.

[31] Chazdon RL, Letcher SG, Van Breugel M, Martínez-Ramos M, Bongers F, Finegan B. Rates of change in tree communities of secondary Neotropical forests following major disturbances. Philosophical Transactions of the Royal Society B: Biological Sciences. 28 Feb 2007; 362(1478): 273-89.

[32] Norden N, Angarita HA, Bongers F, Martínez-Ramos M, Granzow-de la Cerda I, Van Breugel M, Lebrija-Trejos E, Meave JA, Vandermeer J, Williamson GB, Finegan B. Successional dynamics in Neotropical forests are as uncertain as they are predictable. Proceedings of the National Academy of Sciences. 30 Jun 2015; 112(26): 8013-8.

[33] Walker LR, Del Moral R. Primary succession and ecosystem rehabilitation. Cambridge University Press. 2003 Feb 13.

[34] Walker LR, Wardle DA, Bardgett RD, Clarkson BD. The use of chronosequences in studies of ecological succession and soil development. Journal of ecology. Jul 2010; 98(4): 725-36.

[35] Ter Steege H, Lilwah R, Ek R, Van Der Hout P, Thomas R, Van Essen J, Jetten V. Composition and diversity of the rain forest in Central Guyana. An addendum to'Soils of the rain forest in Central Guyana'. Tropenbos Guyana reports 1999.

[36] Hurbert O, Gharbarran G, Funk VA. Preliminary Biodiversity Map of Guyana. Washington DC. 1995.

[37] Pickett ST. Space-for-time substitution as an alternative to long-term studies. Long-term studies in ecology. New York: Springer. 1989.

[38] Molnár Z. The land-use historical approach to study vegetation history at the century scale. In Proceedings of "Research, conservation, management" conference. Aggtelek: Aggteleki Nemzeti Park Igazgatóság. 1997; 345354.

[39] Fukami T, Wardle DA. Long-term ecological dynamics: reciprocal insights from natural and anthropogenic gradients. Proceedings of the Royal Society B: Biological Sciences. 22 Oct 2005; 272(1577): 2105-15.

[40] Mueller Dombois D, Ellenberg H. Aims and methods of vegetation ecology. 1974.

[41] Magurran AE. Biological diversity. Current Biology. 22 Feb 2005; 15(4): 116-8.

[42] Ismail MH, Zaki PH, Fuad MF, Jemali NJ. Analysis of importance value index of unlogged and logged peat swamp forest in Nenasi Forest Reserve, peninsular Malaysia. International Journal of Bonorowo Wetlands. 20 Aug 2017; $7(2): 74-8$.

[43] Hutchison K. A test for comparing Shannon-Wiener diversity indices. J. Theor. Biol. 1970; 29: 151-4.

[44] Clarke KR, Warwick RM. Change in marine communities. An approach to statistical analysis and interpretation. Jun 2001; 2: 1-68.

[45] Huston M, Smith T. Plant succession: life history and competition. The American Naturalist. 1 Aug 1987; 130(2): 168-98.

[46] Lohbeck M, Lebrija-Trejos E, Martínez-Ramos M, Meave JA, Poorter L, Bongers F. Functional trait strategies of trees in dry and wet tropical forests are similar but differ in their consequences for succession. PloS one. 2015 Apr 28.

[47] Holl KD, Loik ME, Lin EH, Samuels IA. Tropical montane forest restoration in Costa Rica: overcoming barriers to dispersal and establishment. Restoration ecology. Dec 2000; 8(4): 339-49. 
[48] Kumar N, Kumar A. Floristic diversity assessment in river sand mining near Palri Bhoptan village, Kisangarh Tehsil, Afmer district, Rajasthan, India. Asian Journal of Earth Sciences. 2014; 7(2): 51-9.

[49] Whittaker RH. Dominance and diversity in land plant communities: numerical relations of species express the importance of competition in community function and evolution. Science. 15 Jan 1965; 147(3655): 250-60.

[50] Pielou EC. Species-diversity and pattern-diversity in the study of ecological succession. Journal of theoretical biology. 1 Feb 1966; 10(2): 370-83.

[51] Habeck JR. Forest succession in the Glacier Park cedar-hemlock forests. Ecology. Sep 1968; 49(5): 872-80. 